Convergence and Divergence in Conceptualising and Planning the Sustainable City: An Introduction

\title{
Andrew Harris
}

Department of Geography

University College London

andrew.harris@ucl.ac.uk

\section{Susan Moore}

Bartlett School of Planning

University College London

susan.moore@ucl.ac.uk 


\title{
Convergence and Divergence in Conceptualising and Planning the Sustainable City
}

\begin{abstract}
This special section navigates the contested terrain of the sustainable city and aims to develop new entry points for interdisciplinary dialogue and research. Six contributions from geography, planning and engineering critically engage with the simultaneous convergence of sustainable city visions and universal models of 'best practice' and the demonstrable divergence in how these visions and models are conceptualised and adopted in specific urban contexts. The papers unpack the implications of an emphasis on models and modelling of the sustainable city in relation to green urbanism, governance, building assessment, masterplanning, pedagogy and critical urban enquiry.
\end{abstract}

Key Words: sustainable city, convergence, policy mobilities, divergence, urban planning

Word Length: 2626 (including references, excluding abstract, title and key words)

Davidson and Gleeson $(2014,186)$ refer to the 'meme' of sustainability, gesturing to the global take-up and mainstreaming of the concept in city planning and policymaking. It has, they argue, 'acquired an aura of goodness, like the words justice or democracy or freedom'. A meme implies a pervasive belief that can quickly replicate itself and is easily imitated (cf Dawkins 1976). The ability to imitate demands identifiable characteristics and measures of comparability, hence the common sense demand for models, tool kits, checklists and exemplars promising to deliver, or at least guide the delivering of the desired outcome - the sustainable city. On the one hand this points to the convergence of sustainable city visions through the domination of a few influential singular city 'models' and their prolific influence on urban policy agendas around the world (e.g. eco-cities of Dongton and Masdar; liveable cities of Vancouver and Melbourne; the creative cities of Barcelona and Portland, to name but a few). These exemplar city models suggest that the sustainable city can be pre-defined and met by following key pathways of enshrined 'best practice' (Guy and Marvin 1999; Bulkeley 2006; McCann and Ward 2010; Hodson and Marvin 2010). Yet, on the other hand, mimesis invokes modification and change as imitation is attempted; copies are never perfect and imitation is often selective, thus it is possible to identify and highlight a tremendous divergence in how 'sustainability' is conceptualised (Howard 1898; WCED 1987; Girardet 1999; Rydin 2010; Davidson 2010; Dobson 2011) and how so-called 'best practices' have been adopted and adapted to specific urban contexts (Crot 2010; Harris and Moore 2012; Moore 2013). This simultaneous convergence and divergence is the process at the heart of this special section.

Six short papers have been brought together which navigate the contested global terrain of urban sustainability and develop new entry points for critical dialogue and research. They explore the role of international masterplanners Elizabeth Rapoport) and building assessment models (James Faulconbridge) in the production and dissemination of globalised models of sustainable urbanism. They delve into new governance ideologies and managerial practices (Mike Raco) and new forms of ecological urban imagineering (C P Pow and Harvey 
Neo). They reflect on the pedagogic parameters involved in framing the sustainable city (Susan Moore, Yvonne Rydin and Brian Garcia) or provide a careful historiography of ecological urbanism (Matthew Gandy). Bringing together planners and geographers, these six papers provide an important spectrum of engagement with ideas of the sustainable city. Some offer a broad overview of the internationalisation of ideas and practices around the sustainable city, drawing on interview material with transnational actors or a systematic survey of websites across several countries. Others use a focus on particular key examples such as the 2012 London Olympics and the Sino-Singapore Tianjin Eco-city to develop critical arguments around the contemporary institutional and ideological framing of the sustainable city. Together they pull together an important repertoire of ways that the sustainable city has been composed and comprised, including spreadsheets, legal contracts, teaching practices, ecological metaphors and planning seminars. They also identify the operation of an urban 'sustainability fix' across different scales, histories and geographies, for instance in seeking new markets as a result of the recent financial crisis in the UK and US, and in efforts at ecological modernisation in rapidly urbanising China. Throughout there is an emphasis on models and modelling of the sustainable city, whether in relation to green urbanism, governance, masterplanning, pedagogy, building assessments or intellectual enquiry.

The papers in this section begin to outline some of the key organisations, technologies and delivery mechanisms that define, shape and instigate sustainable urbanism, and the particular tracks and routes in which it travels and is understood. Elizabeth Rapoport identifies a core of international architecture, engineering and planning firms based in North America and Western Europe which are 'disproportionately represented on projects where sustainability is a key element' (2), although C.P. Pow and Harvey Neo's work also emphasises inter-Asian transfers of eco-city ideas, especially between Singapore and China. James Faulconbridge notes how there is an increasing international reach of UK and USoriginating mobile sustainable building assessment models, while Mike Raco emphasises how an elite group of business service provider companies have come to dominate in providing governmental advice around sustainability agendas as they are seen to possess the necessary capacities and expertise to oversee increasingly complex and expensive development processes. Importantly, as Susan Moore and her colleagues highlight, this global network of sustainable city actors, approaches and procedures is fed by a proliferating range of specialist sustainable city higher education programmes.

This core set of agents and components of the sustainable city, operating through command centres such as London and mobilised through particular geographical channels, provides a relatively standardized menu of actors, ideas, terms and techniques. Rapoport's research on masterplanning around sustainable urban projects reveals 'a fairly uniform and consistent set of ideas' (4). Likewise Moore et al. argue that a rhetorical set up of 'common problems' (2) around urban sustainability has often led to a series of common solutions in higher education programmes, while Raco emphasises how particular contractual agreements have been used to narrowly frame possible dimensions to urban sustainability. This meets what Faulconbridge calls a 'desire for global consistency' (13) that renders places commensurable, albeit with some scope for local adaptability. Sustainable urbanism, complete with examples of 'best practice', 'industry standards', and technical checklists, offers a 'global' model, aesthetic or brand that can be easily marshalled and mobilised in entrepreneurial attempts at fostering, legitimising and promoting contemporary forms of 
urban development. However, an emphasis on emulation, inter-referencing and benchmarking should not lead to assumptions that actors necessarily passively adopt globalised and universal models of urban sustainability. Rapoport shows how clients of Western planning consultants in cities of the Middle East often strategically assume sustainable credentials at an early stage of the development process, while Moore et al (6) suggest many students use sustainable city education to position themselves within international job market opportunities.

Yet this apparent globalised homogeneity in sustainable urbanism has been accompanied by mutation, contradiction and contingency. Several of the authors in this section draw on McCann and Ward's (2010) relationality-territoriality dialectic in exploring the global mobility of ideas around sustainable urbanism. The sustainable city, although mobilised through a transnational network of transfer agents, is seen as routed through particular urban contexts with specific histories, political systems and cultural milieus. Perhaps most strikingly, Pow and Neo (2) detail how the notion of modelling green urbanism in China is shaped through local traditions and vocabulary, 'because in both traditional Confucian and Maoist thoughts, emulating successful individuals and processes were often celebrated as an exemplary form of learning'. Moore et al. detail how sustainable city higher education programmes, although sharing key similarities in their rhetoric and framing of urban problems, do recognise 'the importance of geographical specificity in the application and implementation of sustainable cities theory and practice' (1), often incorporating forms of situated learning within the educational experience.

What is crucial is to consider sustainability as an 'essentially contested concept' (Dobson, $2011,1229)$. Rather than the meme of sustainability, it is more accurate perhaps to think of sustainability as a memeplex (or meme-complex), that is to say a collection or grouping of memes that have evolved into a mutually supportive relationship or more simply, a set of ideas that reinforce each other (Blackmore 1999). Ultimately, the same idea, sustainability, can be expressed with different memes supporting it. This distinction between concept and conceptions underpins the recent promotion of the pathways approach to understanding and researching urban sustainability (Guy and Marvin 1999; Williams 2010; Leach et al 2010). Forerunners in this endeavour, Guy and Marvin stressed back in 1999 that a multiple vision framework originates from the first principle that 'the promotion of sustainable cities must start with a contested vision of the sustainable city' (p. 272). This emphasises the social construction of the image of what constitutes the sustainable city; it privileges the competing logics of innovation without prioritising the technical over the social and it sees pathways towards a sustainable city emerging not through the overcoming of social barriers by technical or managerial innovation but through the contextual richness of coalitions of interest and the bottom-up promotion of initiatives, strategies and plans through partnership, not merely consensus, across interests. Seen in this way, it is argued the sustainable city 'needs to be treated as an open or empty concept which is filled by sets of competing claims about what the sustainable city might become' (Guy and Marvin 1999, 273). Whitehead (2003) similarly laments the reification of the sustainable city as an ontological object, by which he means 'analyses tend to assume the prior existence of a thing called a sustainable, or indeed unsustainable, city and ignore the complex discursive processes and socio-political struggles through which sustainable cities are produced' ( $p$. 1187). In this way, the sustainable city takes on a neutrality and apolitical overlay that 
belies its social construction. As Whitehead (2003) asserts, sustainable cities 'are never finished objects', whether a tangible object or a location on a map - 'but rather in a constant state of becoming' (p.1187).

Guy and Marvin (1999) have therefore cautioned that the domination of singular, largely technocratic visions, supported by best practice rhetoric and regulatory policing of nontechnical behaviours (the so-called barriers to resource efficiencies) potentially squeeze out alternative logics that find it difficult to gain footing in the social context themselves, thus limiting debate about the types of sustainable urban futures possible and promoting a selective outcome. This may indeed be an unconscious process, symptomatic of policy formulation practices more generally, wherein as Sorenson (2010) explains 'policy windows open when pressing problems are linked to solutions and both are swept up in a political moment when political will is generated for implementation' (p. 121). The identification of a problem is closely related to the availability of solutions; wherein 'solutions make problems comprehensible and action imaginable' (p.121). As Faulconbridge notes in this issue, this often translates into weak or 'light-green' interpretations of consensus-based urban sustainability being popularised, restricting opportunities to use vernacular and more locally sensitive sustainability solutions and building designs. Moreover, this potentially does more harm than allowing unchecked patterns of urban development to continue (Swyngedouw, 2010). This is because it 'foreclose[s] the conditions of possibility under which more radical approaches to urban socio-environmental development could flourish, while helping to maintain a distinctly post-political and post-democratic urban system' (Whitehead, 2012, 29). Mike Raco for instance details how the recent compartmentalising of sustainability projects into 'a series of definable tasks whose inputs and outcomes can be measured and calculated' (1) closes down democratic debate about more sustainable urban futures.

Against these uncontested, inert and deliberately limited understandings, the papers in this special section seek to open up wider ways of conceptualising and planning the sustainable city. In particular they point to how a focus on models of the 'sustainable city' can develop important new empirical perspectives and conceptual approaches within work on urban policy mobilities. This includes exploring how certain key sustainable city models crystallise from 'a bundle of practices and conventions' (Rapoport, 5) and how they are rendered visible and mobile - or otherwise. This also includes explicitly investigating processes of urban learning around the sustainable city, such as in higher education programmes. These papers also point to the need for further work on the particular microspaces and 'events along the way' (McCann, 2011) that produce - and challenge - ideas and ideals of the sustainable city, and the intellectual histories of key terms such as 'ecology' that underpin conceptual and disciplinary framings of this urban field. The papers also begin to identify potential political responses to addressing the inherent socio-ecological contradictions of urban sustainability. These will require developing pedagogical and institutional approaches that better embrace the productive tensions that emerge from sustainable city knowledge and practice. This will be key in tackling what Raco (7) defines as the 'in-built expansionism' of recent managerial models emphasising objectives of sustainable urbanism. It is hoped that the conceptual and critical perspectives drawn together here might allow a broader diversity of approaches, definitions, histories and concepts around the sustainable city to be flagged; ones that leave more room for democratic experimentation, grassroots 
innovations, vernacular sustainable design initiatives, and alternative forms of ecourbanism.

\section{Acknowledgements}

With thanks to participants at the 'Towards Convergence or Divergence in Planning the Sustainable City?' workshop which took place in March 2010 at University College London, supported by an EPSRC funded programme, 'Bridging the Gaps'. Thanks as well to Dr Tim Bunnell from the National University Singapore's Asia Research Institute, who acted as an external discussant at the event.

\section{References}

Blackmore S 1999 The Meme Machine Oxford, Oxford University Press.

Bulkeley, H 2006 Urban sustainability: learning from best practice? Environment and Planning A 38 1029-1044.

Crot L 2010 Transnational urban policies: 'relocating' Spanish and Brazilian models of urban planning in Buenos Aires Urban Research and Practice 3(2) 119-137.

Davidson K and Gleeson B 2014 The sustainability of an entrepreneurial city? International Planning Studies 19(2) 173-191.

Davidson M 2010 Sustainability as ideological praxis: the acting out of planning's master signifier City 14(3) 1-17.

Dawkins R 1976 The Selfish Gene Oxford, Oxford University Press.

Dobson A 2011 STEPS - Norms, complexity, deliberation Environment and Planning A 43 1229-1231.

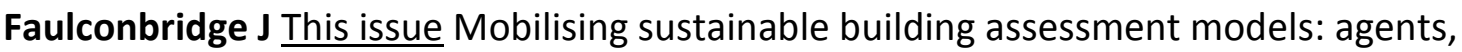
strategies and local effects Area

Gandy $\mathbf{M}$ This issue From urban ecology to ecological urbanism: an ambiguous trajectory Area

Girardet H 1999 Creating Sustainable Cities Cambridge, Green Books. 
Guy S and Marvin S 1999 Understanding sustainable cities: competing urban futures European Urban and Regional Studies 6(3) 268-275.

Harris A and Moore S 2012 Planning Histories and Practices of Circulating Urban Knowledge International Journal of Urban and Regional Research 37(5) 1499-1509.

Hodson M and Marvin S 2010 Can cities shape socio-technical transitions and would we know if they were? Research Policy 39 477-485.

Howard E 1898(2003) To-morrow: A peaceful pathway to real reform Abingdon Oxon, Routledge.

Leach M, Scoones I and Stirling A 2010 Dynamic sustainabilities: a response Environment and Planning A 43 1235-1237.

McCann E 2011 Urban policy mobilities and global circuits of knowledge: Toward a research agenda Annals of the Association of American Geographers 101 107-130.

McCann E and Ward K 2010 Relationality/Territoriality: toward a conceptualization of cities in the world Geoforum 41(2) 175-184.

Moore S, Rydin Y and Garcia B This issue Sustainable city education: the pedagogical challenge of mobile knowledge and situated learning_Area

Moore S 2013 What's wrong with best practice? Questioning the typification of New Urbanism Urban Studies 50(11) 2371-2387.

Pow C P and Neo $\mathbf{H}$ This issue Modelling green urbanism in China Area

Raco $\mathbf{M}$ This issue Sustainble city-building and the new politics of the possible: reflections on the governance of the London Olympics 2012 Area

Rapoport E This issue Globalising sustainable urbanism: the role of international masterplanners Area

Rydin Y 2010 Governing for Sustainable Urban Development London, Earthscan/ James \& James.

Sorenson A 2010 Chapter 6 Urban Sustainability and Compact Cities ideas in Japan in Healey $\mathbf{P}$ and Upton $\mathbf{R}$ eds Crossing Borders: International Exchange and Planning Practices Abingdon Oxon, Routledge 117-140.

Swyngedouw E 2010 Apocalypse forever? Post-political populism and the spectre of climate change theory Culture \& Society 27(2/3) 213-232. 
Whitehead M 2003 (Re)Analysing the Sustainable City: Nature, Urbanisation and the Regulation of Socio-environmental Relations in the UK Urban Studies 40(7) 1183-1206.

Whitehead M 2012 The Sustainable City: an obituary? On the future form and prospects of sustainable urbanism in Flint J and Raco M eds The Future of Sustainable Cities: critical reflections Bristol, Policy Press 29-46.

Williams K 2010 Sustainable Cities: research and practice challenges International Journal of Sustainable Development 1(1-2) 128-132.

World Commission on Environment and Development 1987 Our Common Future (The Brundtland Report) Oxford, WCED/Oxford University Press. 